\title{
Program Pemberdayaan Ekonomi dan Kesehatan Keluarga melalui Pelatihan Pembuatan Virgin Coconut Oil (Vco) untuk Ibu - ibu Dan Remaja Putri Desa Gelung Kecamatan Panarukan - Situbondo
}

\section{Ekonomic Empowerment and Family Health Program through Training in The Production Of Virgin Coconut Oil (Vco) For Women and Teenage Girls in Gelung Village, Panarukan Sub- District Situbondo}

\author{
Ratnaning Tyasasih ${ }^{1)}$, Triska Dewi Pramitasari ${ }^{2)}$ \\ 1email: ratnaning018@gmail.com \\ Universitas Abdurachman Saleh Situbondo
}

\begin{abstract}
The coastal area of Pathek Beach, precisely the Gelung Village of Panarukan District has one commodity which in its development requires support and cooperation with various subsystems namely coconut. However, parts of coconut have not been used to be processed as medicines and cosmetic ingredients such as virgin coconut oil (Virgin Coconut Oil) has not been done by farmers or the general public. Some of the causes are the lack of experts, lack of skills and knowledge, lack of capital and the slow development of technology in the area. The solutions that can be given from these problems include increasing the knowledge of community groups on the importance of VCO products to health. Another solution is by increasing the ability and capacity of community groups through counseling and training that will provide opportunities for increased income through efforts to establish independent businesses of community groups (women and young women) ). The Community Partnership Program (PKM) activity plan consists of 2 stages: training in making Virgin Coconut Oil (VCO) and counseling the benefits and ways to use VCO for health. The output achieved was that participants had begun to realize and understand the important role of the development of agro-industry especially $V C O$ oil as a means of supporting health and increasing family income. They also start to be aware of the opportunities and challenges of VCO agro-industry as an effort to improve skills and income from agriculture and increase participants knowledge of VCO making technology at an optimal household scale.
\end{abstract}

Keywords: Coconut, Virgin Coconut Oil (VCO), Family Health

Abstrak: Daerah pesisir Pantai Pathek tepatnya Desa Gelung Kecamatan Panarukan memiliki satu komoditas yang dalam pengembangannya memerlukan dukungan dan kerjasama dengan berbagai subsistem yaitu kelapa. Namun pemanfaatan bagian buah kelapa menjadi produk olahan yang berfungsi sebagai obat dan bahan kosmetik seperti minyak kelapa murni (Virgin Coconut Oil) belum banyak dilakukan oleh petani maupun masyarakat umum. Beberapa penyebabnya adalah masih kurangnya tenaga-tenaga ahli, minimnya keterampilan dan pengetahuan, kecilnya modal yang dimiliki dan lambatnya perkembangan teknologi di daerah tersebut. Solusi yang dapat diberikan dari permasalahan tersebut diantaranya meningkatkan pengetahuan kelompok masyarakat akan pentingnya produk $V C O$ terhadap kesehatan serta meningkatkan kemampuan dan 


\section{INTEGRITAS : Jurnal Pengabdian}

Vol 3, No 1, Juli 2019

ISSN 2580-7978 (Cetak) ISSN 2615-0794 (Online)

kapasitas kelompok masyarakat melalui penyuluhan dan pelatihan yang akan memberikan peluang peningkatan penghasilan melalui upaya pembentukan usaha mandiri dari kelompok masyarakat (ibu-ibu dan remaja putri). Rencana kegiatan Program Kemitraan Masyarakat (PKM) ini terdiri dari 2 tahapan yaitu : pelatihan pembuatan Virgin Coconut Oil (VCO) dan penyuluhan manfaat dan cara pakai $V C O$ untuk kesehatan. Adapun luaran yang telah dicapai adalah para peserta sudah mulai menyadari dan mengerti pentingnya peranan pengembangan agroindustri khususnya minyak VCO sebagai sarana penunjang kesehatan dan menambah pendapatan keluarga, mengetahui peluang dan tantangan agroindustri VCO dengan benar dalam upaya meningkatkan ketrampilan dan pendapatan dari bidang pertanian serta para peserta bertambah pengetahuannya tentang teknologi pembuatan VCO pada skala rumah tangga secara optimal.

Kata Kunci : Kelapa, Virgin Coconut Oil (VCO), Kesehatan Keluarga

\section{PENDAHULUAN}

Kabupaten Situbondo dengan luas wilayah $1.638,50 \mathrm{~km}^{2}$ memiliki tujuh belas kecamatan antara lain, Kecamatan Arjasa, Kecamatan Asembagus, Kecamatan Banyuglugur, Kecamatan Banyuputih, Kecamatan Besuki, Kecamatan Bungatan, Kecamatan Jangkar, Kecamatan Jatibanteng, Kecamatan Kapongan, Kecamatan Kendit, Kecamatan Mangaran, Kecamatan Mlandingan, Kecamatan Panji, Kecamatan Situbondo, Kecamatan Suboh, Kecamatan Sumbermalang, dan Kecamatan Panarukan. Dari ketujuh belas kecamatan tersebut, Kecamatan Panarukan yang akan menjadi pokok pembahasan dalam tulisan ini.

Nama Panarukan terkenal karena merupakan ujung timur dari jalan Raya Post yang dibangun oleh Gubenur Jendral Deandles pada masa penjajahan Belanda di Indonesia. Panarukan sendiri terdiri dari delapan desa, yaitu Desa Kilensari, Desa Wringin Anom, Desa Paowan, Desa Sumberkolak, Desa Peleyan, Desa Duwet, Desa Alasmalang, dan Desa Gelung. Total luas wilayah Kecamatan Panarukan adalah 54,55 $\mathrm{km}^{2}$.

Kecamatan Panarukan merupakan daerah pesisir di wilayah Kabupaten Situbondo. Dari delapan desa yang ada di kecamatan Panarukan, tiga diantaranya memiliki wilayah pantai yaitu Pantai Panarukan di Desa Kilensari, Pantai Pathek di Desa Gelung, dan Pantai Berigheen di Desa Peleyan. Pantai tersebut dikelola menjadi tempat pariwisata dan kegiatan perdagangan. Pantai yang menjadi tempat 
INTEGRITAS : Jurnal Pengabdian

Vol 3, No 1, Juli 2019

ISSN 2580-7978 (Cetak) ISSN 2615-0794 (Online)

pariwisata adalah pantai Pathek dan Pantai Berigheen. Ditandai dengan adanya sarana dan prasarana yang menunjang pariwisata seperti penginapan, rumah makan, dan area pemancing ikan. Sedangkan pantai yang dikelolah untuk kegiatan perdagangan adalah pantai yang berada di Desa Kilensari.

Dibalik potensi yang sudah ada terselip kekurangan yang menghambat laju perkembangan potensi tersebut. Diantaranya adalah kekurangan tenaga ahli dalam mengelolah potensi sumber daya alam di kecamatan Panarukan. Pengelola kurang mampu menerapkan perkembangan teknologi yang sudah maju untuk mengembangkan potensi tersebut. Terbukti dari masih sederhananya sarana dan prasarana pariwisata di Pantai Pathek yang terkesan tertinggal jauh jika dibandingkan dengan sarana dan prasarana di tempat pariwisata lain. Contohnya jalan menuju wisata Pantai Pathek yang rusak dan kurangnya penerangan di sepanjang jalan maupun di tempat wisatanya.

Saat ini semua peluang tersebut belum mampu menjadi potensi dari Kecamatan Panarukan karena belum dapat dikelola secara maksimal. Beberapa kendala yang mendasari terhambatnya peluang perkembangan sektor-sektor tersebut adalah masih kurangnya tenaga-tenaga ahli, kecilnya modal yang dimiliki dan lambatnya perkembangan teknologi di daerah tersebut.

Berdasarkan data kependudukan tahun 2012, jumlah Penduduk Kecamatan Panarukan sebanyak 51.645 jiwa. Dari jumlah penduduk yang tersebar di delapan desa yang terbanyak adalah Desa Kilensari sejumlah 12.478 jiwa dan yang terjarang adalah Desa Duwet sejumlah 2.910 jiwa. Dari sekian penduduk, jumlah murid SD/Mi hanya sekitar 5.919 siswa. Dari data tersebut membuktikan bahwa tingkat pendidikan di Kecamatan Panarukan masih rendah. Kurangnya antusias masyarakat untuk bersekolah berpengaruh pada pemenuhan tenaga-tenaga professional di daerah tersebut. Inilah yang menjadi kendala dasar yang menghambat perkembangan Kecamatan Panarukan

Rendahnya pengetahuan dan kurangnya tenaga professional inilah yang menyebabkan timbulnya kendala-kendala yang lain. Seperti kurangnya modal karena masyarakat tidak mampu menarik minat investor untuk menanamkan 
INTEGRITAS : Jurnal Pengabdian

Vol 3, No 1, Juli 2019

ISSN 2580-7978 (Cetak) ISSN 2615-0794 (Online)

modalnya. Serta ketidakmampuan masyarakat memanfaatkan teknologi untuk memudahkan mereka mengelola kekayaan yang ada. Selama ini masyarakat dominan menggunakan cara dan alat tradisional dalam mengolah sumber daya yang mereka miliki. Dengan keterbatasan kemampuan dan alat ini tentunya mempengaruhi akan hasil produksi yang relatif kurang baik dan belum mampu bersaing dengan produk-produk dari daerah lain.

Masyarakat Desa Gelung, Kecamatan Panarukan Kabupaten Situbondo pada umumnya menanam tanaman kelapa di ladang dan pekarangan rumahnya. Selama ini buah kelapa yang dihasilkan dari pekarangan mereka langsung dijual pada tengkulak atau pedagang keliling dengan harga yang sangat murah, padahal kalau buah kelapa tersebut terlebih dahulu melalui proses pengolahan maka produk olahan yang dihasilkan memiliki nilai jual berlipat ganda dibandingkan apabila dijual dalam bentuk butiran kelapa. Namun kendala yang dihadapi pada umumnya adalah masih kurangnya tenaga-tenaga ahli, minimnya ketrampilan dan pengetahuan, kecilnya modal yang dimiliki dan lambatnya perkembangan teknologi di daerah tersebut.

Melihat kenyataan tersebut membuka peluang bagi kita untuk lebih meningkatkan nilai jual buah kelapa yang ada dengan terlebih dahulu memproses buah kelapa tersebut menjadi produk olahan yang memiliki nilai ekonomis lebih tinggi. Salah satu upaya yang dapat dilakukan yaitu dengan memberikan pelatihan cara memproses buah kelapa menjadi produk olahan minyak kelapa murni (Virgin Cocconut Oil) yang banyak diminati oleh masyarakat sebagai bahan baku obat dan kosmetika yang memiliki nilai jual cukup tinggi. Adanya kegiatan pelatihan ini diharapkan dapat mencapai tujuan yang diharapkan, yaitu memberikan pengetahuan dan ketrampilan kepada ibu rumah tangga dan remaja putri. Setelah selesai mengikuti pelatihan diharapkan mereka dapat membuka peluang usaha untuk meningkatkan pendapatan keluarga sekaligus meningkatkan nilai jual bahan baku kelapa.

\section{METODE PELAKSANAAN}


INTEGRITAS : Jurnal Pengabdian

Vol 3, No 1, Juli 2019

ISSN 2580-7978 (Cetak) ISSN 2615-0794 (Online)

\section{Metode Pendekatan}

Dalam Program Kemitraan Masyarakat ini, metode pendekatan yang digunakan untuk mengatasi berbagai persoalan yang dihadapi oleh kelompok masyarakat yaitu dengan cara pendekatan partisipatif aktif secara berkelanjutan antara tim pengusul dengan mitra, sebagai pengendali program Kemitraan Masyarakat berperan aktif melakukan pendampingan dan pembinaan secara berkala kepada mitra.

\section{Prosedur Kerja}

Tahap persiapan, koordinasi pelaksanaan program selama 8 bulan antara tim pengusul, mitra pada tahap ini akan dilakukan persiapan-persiapan yang berhubungan dengan pelaksanaan program yaitu mempersiapkan segala peralatan dan bahan yang diperlukan untuk pelatihan pembuatan produk $V C O$.

Tahap pelaksanaan, pelaksanaan program sesuai dengan kesepakatan bersama antara tim pengusul dan kelompok masyarakat yaitu berupa penyuluhan/pelatihan/workshop antara lain :

a. Penyuluhan dan pengenalan mengenai apa dan manfaat apa saja yang terdapat dalam produk $V C O$

b. Memberikan pelatihan pembuatan produk $V C O$

c. Memberikan pengarahan tentang cara pemakaian produk VCO untuk kesehatan

Tahap monitoring dan evaluasi, pendampingan dan penilaian atas capaian program yang telah dilaksanakan antara tim pengusul terhadap mitra.

\section{Rencana Kegiatan}

Program Kemitraan Masyarakat (PKM) ini diikuti oleh 12 orang ibu-ibu dan remaja putri dengan pokok bahasan dan pelatihan meliputi :

a. Pelatihan pembuatan Virgin Coconut Oil (VCO)

b. Cara penggunaan dan manfaat $V C O$

Tahap 1 : Pelatihan Pembuatan Virgin Coconut Oil (VCO) 
INTEGRITAS : Jurnal Pengabdian

Vol 3, No 1, Juli 2019

ISSN 2580-7978 (Cetak) ISSN 2615-0794 (Online)

Adapun alat dan bahan-bahan yang diperlukan dalam proses pembuatan Virgin Coconut Oil (VCO) adalah sebagai berikut :

Tabel 1. Alat yang Digunakan untuk Pembuatan VCO

\begin{tabular}{|c|l|c|c|}
\hline No. & \multicolumn{1}{|c|}{ Material } & $\begin{array}{c}\text { Justifikasi } \\
\text { Pemakaian }\end{array}$ & Kuantitas \\
\hline \hline 1 & Mesin Parut Kelapa Listrik (180 watt) & Set & 3 \\
\hline 2 & Baskom penampung adonan (kelapa parut + air mineral) & Buah & 6 \\
\hline 3 & Saringan santan aluminium & Buah & 12 \\
\hline 4 & Kain katun (segi empat) & Buah & 12 \\
\hline 5 & Water dispenser transparan (penampung santan) & Buah & 12 \\
\hline 6 & Mixer duduk & Buah & 4 \\
\hline 7 & Toples transparan 10 ltr & Buah & 24 \\
\hline 8 & Penyaring Minyak & Buah & 12 \\
\hline 9 & Sendok sayur pipih & Buah & 12 \\
\hline 10 & Tissue non parfum & Box & 12 \\
\hline
\end{tabular}

Tabel 2. Bahan Baku

\begin{tabular}{|c|l|c|c|}
\hline No. & \multicolumn{1}{|c|}{ Material } & $\begin{array}{c}\text { Justifikasi } \\
\text { Pemakaian }\end{array}$ & Kuantitas \\
\hline \hline 1 & Kelapa & Buah & 120 \\
\hline 2 & Air Mineral & Liter & 120 \\
\hline
\end{tabular}

Kunci dari pembuatan $V C O$ dengan metode sentrifugasi adalah kecepatan pemutaran yaitu $20.000 \mathrm{rpm}$. Disamping itu faktor waktu juga menjadi pembatas dalam pemutaran tersebut. Waktu yang dibutuhkan untuk menjadikan VCO dengan kualitas baik yaitu sekitar 15 - 30 menit. Alat yang digunakan untuk memutar santan dinamakan dengan sentrifuse (dalam kesempatan ini menggunakan mixer). Pembuatan VCO dengan metode sentrifugasi memiliki kelebihan diantaranya adalah:

a. Berwarna jernih dan berbau khas minyak kelapa

b. Daya simpan lama, sekitar 10 tahun tanpa bahan pengawet

c. Proses pembuatan sangat cepat, hanya membutuhkan waktu sekitar 15-30 menit

d. Kandungan asam lemak rantai sedang tidak mengalami denatures, demikian juga dengan kandungan antioksidannya.

Keunggulan inilah yang diharapkan dapat menjadikan ibu-ibu dan remaja putri lebih giat dalam membuat Virgin Coconut Oil (VCO) dan kemudian bisa digunakan sendiri atau dijual (dipasarkan). Adapun tahap pelaksanaan praktek 
INTEGRITAS : Jurnal Pengabdian

Vol 3, No 1, Juli 2019

ISSN 2580-7978 (Cetak) ISSN 2615-0794 (Online)

pembuatan VCO dengan metode sentrifugasi dari awal hingga akhir sebagai berikut:

a. Kelapa dikupas dengan cara memisahkan daging buah dengan kulit sabut dan tempurungnya, lalu air dibuang. Kelapa yang sudah dikupas ditempatkan di dalam wadah dan siap untuk diparut

b. Parutan kelapa dicampur dengan air lalu diperas, dengan perbandingan 5 liter air untuk 10 buah kelapa. Hasil perasan kelapa ditampung dalam water dispenser. Proses pemerasan kelapa ini dilakukan dua kali. Jadi, ampas hasil perasan pertama dicampur lagi dengan air bersih lalu diperas dan hasil perasan disaring dan ditampung di dalam water dispenser. Proses pemerasan ini sangat penting dan harus segera dilakukan karena jika hasil parutan kelapa terlalu lama didiamkan rasanya akan asam dan tidak biasa menghasilkan VCO.

c. Air hasil perasan yang ada di water dispenser didiamkan sekitar 2 jam, sehingga terbentuk 2 lapisan. Lapisan atas adalah kanil (krim) dan bagian bawah adalah air yang harus dibuang dengan membuka kran dibagian bawah water dispenser.

d. Setelah air terbuang, proses selanjutnya kanil (krim) dapat diolah dengan metode sentrifugasi yaitu kanil dimixer dengan kecepatan 3 selama 30 menit. Hasil mixer di tamping dalam toples transparan lalu ditutup rapat. Diamkan selama 12-36 jam.

e. Selanjudnya akan terbentuk 3 lapisan. Lapisan bawah adalah air, lapisan tengah adalah blondo dan lapisan atas adalah $V C O$.

f. $\quad V C O$ siap diambil menggunakan sendok sayur pipih dengan cara menyendok minyak lalu tuang ke dalam saringan minyak yang sudah dilapisi tissue non parfum yang dibawahnya terdapat toples tranparan penampungan $V C O$. Lakukan hingga lapisan minyak habis.

g. $V C O$ siap di kemas ke botol kemasan $125 \mathrm{ml}$ dan siap digunakan atau di jual.

\section{Tahap 2 : Penyuluhan Manfaat dan Cara Pakai VCO untuk Kesehatan}


INTEGRITAS : Jurnal Pengabdian

Vol 3, No 1, Juli 2019

ISSN 2580-7978 (Cetak) ISSN 2615-0794 (Online)

Penggunaan $V C O$ secara teratur dapat memberikan manfaat yang maksimal bagi kesehatan, terutama berfungsi untuk membantu proses penyembuhan dan mengatasi berbagai penyakit. Namun, meskipun tidak menimbulkan efek samping yang berbahaya, konsumsi $V C O$ tetap perlu diperhatikan. Hal ini dilakukan agar mendapat khasiat yang maksimal. Pada dasarnya semakin banyak mengkonsumsi VCO maka efeknya bagi kesehatan menjadi lebih baik. Salah satu contoh penggunaan $V C O$ dalam kesehatan dan penyembuhan adalah jika $V C O$ digunakan sebagai suplemen. Beberapa ahli berpendapat bahwa untuk orang dewasa perlu mengkonsumsi 3,5 sendok makan $( \pm 50 \mathrm{~g})$ VCO setiap hari. Akan tetapi, jika digunakan untuk membantu penyembuhan penyakit beberapa ahli menyatakan bahwa konsumsi $V C O$ sampai sekurang-kurangnya $1 \mathrm{~g} / \mathrm{kg}$ bobot badan masih aman. Sedangkan jika digunakan sebagai obat luar, maka cukup dioleskan secara merata ke permukaan yang sakit atau kesekujur tubuh sebanya 3 kali sehari.

Manfaat VCO dalam bidang kesehatan (Anonim, 2007), diantaranya adalah sebagai berikut :

1. Merupakan antibakteri, antivirus, antijamur dan antiprotozoal alami

Di dalam tubuh, asam laurat akan diubah menjadi monolaurin dan asam kaprat menjadi monokaprin. Keduanya bersifat sebagai antibakteri, antivirus, antijamur dan antiprotozoal karena struktur membrane asam lemak jenuh VCO menyerupai membran lemak dari virus / bakteri serta ukuran molekul VCO kecil maka VCO mudah masuk ke dalam membrane dan menghancurkan mikroorganisme.

2. Menjaga kesehatan jantung dan pembuluh darah

Penelitian menunjukkan adanya hubungan penyakit jantung dan pembuluh darah dan infeksi virus / bakteri yang akan menyebabkan pembentukan plak di pembuluh darah. VCO bersifat antibakteri / virus maka dapat membantu mencegah pembentukan plak dengan cara membunuh mikroorganisme pencetus timbulnya plak. Selain itu salah satu penyebab penyakit jantung adalah kadar kolesterol darah yang tinggi. Penumpukan kolesterol disebabkan konsumsi lemak yang berlebihan dalam menu sehari-hari sehingga 
INTEGRITAS : Jurnal Pengabdian

Vol 3, No 1, Juli 2019

ISSN 2580-7978 (Cetak) ISSN 2615-0794 (Online)

kelebihannya disimpan dalam tubuh. Dalam VCO terdapat MCFA yang mudah dimetabolisme untuk menghasilkan energi tidak ditimbun sebagai lemak tubuh. Selain itu konsumsi rutin $V C O$ juga mencegah terjadinya pengentalan darah (akibat agregasi trombosit) dan mencegah terjadinya penyempitan pembuluh darah (aterosklerosis)

3. Membantu mencegah penyakit osteoporosis

Osteoporosis adalah merupakan penyakit degenerative akibat kekurangan kalsium sehingga tulang menjadi keropos. Osteoporosis dapat disebabkan oleh radikal bebas yang teroksidasi pada proses pembentukan tulang. Radikal bebas dapat diatasi oleh kandungan lemak jenuh yang terkandung dalam $V C O$. Asam lemak dalam $V C O$ berfungsi sebagai antioksidan sehingga akan melindungi tulang dari radikal bebas perusak tulang. Salah satu antioksidan dalam $V C O$ adalah senyawa sterol. Zat ini seperti lemak dan bermanfaat dalam pembentukan pregnenolon yang berfungsi untuk memproduksi progesterone bagi wanita. Bagi wanita ketersediaan progesterone sangat penting karena ketidakseimbangan progesterone dan estrogen akan menyebabkan osteoporosis. Konsumsi VCO juga sangat baik membantu proses penyerapan mineral penting bagi tulang yaitu kalsium dan magnesium.

4. Membantu mencegah penyakit diabetes

Diabetes mellitus dikenal juga sebagai kencing manis. Gejala kencing manis terutama terjadi akibat menumpuknya glukosa dalam darah sehingga dikeluarkan bersama urin. Dalam kondisi ini produksi insulin dari pancreas menurun sehingga metabolism terganggu. Hal ini menyebabkan glukosa tidak biasa masuk ke dalam sel sehingga konsentrasi glukosa darah meningkat. Timbunan glukosa tersebut tidak dapat dimanfaatkan untuk menghasilkan energi dan akhirnya dibuang bersama urin. Insulin berfungsi mengubah glukosa menjadi energi untuk sel. Glukosa darah tidak dapat langsung digunakan sebagai energi harus ditransfer terlebih dahulu ke dalam sel melalui proses oksidasi dalam sel. Selain itu insulin juga mengubah glukosa menjadi energi cadangan (glikogen dan lemak). Jika glukosa darah berlimpah 
INTEGRITAS : Jurnal Pengabdian

Vol 3, No 1, Juli 2019

ISSN 2580-7978 (Cetak) ISSN 2615-0794 (Online)

akan diubah menjadi glikogen dan disimpan di hati dan otot. Sementara lemak disimpan dalam jaringan lemak. Kandungan MCFA dalam VCO mampu merangsang produksi insulin sehingga membantu proses perubahan glukosa menjadi energi untuk sel. Selain itu, $V C O$ tidak membutuhkan insulin untuk dapat dibakar untuk menghasilkan energi sehingga hal ini sangat menguntungkan penderita kencing manis yang telah mengalami kekurangan kadar insulin tubuh. Pada saat VCO dibakar turut dibakar pula glukosa dan lemak yang sebelumnya telah tertimbun sehingga kadar gula dalam darah relative normal.

5. Membantu mencegah penyakit liver

Virus hepatitis adalah virus yang memiliki selubung lemak di bagian luarnya sehingga sulit ditembus oleh obat. Struktur asam lemak jenuh rantai sedang dalam VCO memiliki struktur yang mirip selubung lemak virus sehingga $V C O$ dapat menembus masuk dan membunuh virus hepatitis. Selain itu VCO juga mencegah kerusakan sel hati akibat radikal bebas yang disebabkan oleh virus, obat atau alcohol karena memiliki efek sebagai antioksidan.

6. Membantu mencegah penyakit kanker

VCO memiliki efek antibakteri maka sel darah putih tersedia cukup untuk menghancurkan dan menghambat pertumbuhan sel kanker. Penelitian pada hewan menunjukkan bahwa VCO menghambat pertumbuhan sel kanker penyebab kanker kolon dan payudara. Selain itu VCO memiliki sifat antioksidan sehingga mencegah pembentukan radikal bebas pemicu timbulnya kanker dan $V C O$ membantu meningkatkan sistem kekebalan tubuh sehingga membantu proses penyembuhan.

7. Menurunkan berat badaan

MCFA dalam $V C O$ dapat langsung masuk aliran darah dan diubah menjadi energi sehingga tidak ditimbun dalam badan. Pada saat VCO dibakar turut dibakar pula asam lemak jenuh rantai panjang (LCFA) sehingga lemak yang ditimbun menjadi berkurang dan berat badan akan turun. Selain itu VCO juga memberi energi dengan cepat sehingga menimbulkan rasa cepat kenyang dan 
INTEGRITAS : Jurnal Pengabdian

Vol 3, No 1, Juli 2019

ISSN 2580-7978 (Cetak) ISSN 2615-0794 (Online)

tidak merasa lapar sampai tiba waktu makan. Proses pembakaran dan suhu badan menjadi lebih tinggi sehingga metabolisme tubuh meningkat dan terjadi pembakaran cadangan lemak tubuh.

8. Menjaga stamina tubuh

Saat daya tahan tubuh menurun, tubuh mengalami kelelahan fisik yang ditandai dengan lemah otot, sakit kepala, infeksi yang hilang timbul, demam, rasa lelah, yang luar biasa dan pembekakan kelenjar tubuh. VCO memberi energi yang cepat dan menambah tenaga serta meningkatkan sistem kekebalan tubuh sehingga tubuh dapat memulihkan dirinya sendiri.

9. Memelihara kesehatan kulit

VCO mengandung pelembab alami dan membantu menjaga kelembaban kulit serta baik digunakan untuk kulit yang kering, kasat dan bersisik. VCO mengandung asam lemak jenuh rantai sedang yang mudah masuk ke lapisan kulit dalam dan mempertahankan kelenturan serta kekenyalan kulit. VCO bersifat antijamur dan antibakteri alami sehingga membantu mencegah dan mengobati infeksi kulit, infeksi jamur kulit, eksim, jerawat, bisul dan lainlain.

10. Pengganti minyak sayur

VCO mengandung minyak jenuh rantai sedang yang bersifat lebih tahan terhadap pemanasan sehingga jika dipakai untuk menggoreng tidak cepat rusak.

\section{HASIL DAN LUARAN YANG DICAPAI}

\section{Hasil Pelaksanaan Kegiatan}

Hasil pelaksanaan kegiatan Program Kemitraan Masyarakat (PKM) dilaksanakan melalui beberapa kegiatan diantaranya adalah pemberian materi serta pengadaan pelatihan yang dilaksanakan dengan baik dan lancar. Pelaksanaan kegiatan pelatihan dilaksanakan dengan metode tatap muka melalui ceramah dan demonstrasi, kemudian dilanjutkan dengan pelatihan pembuatan VCO (Virgin Coconut Oil) dengan bahan dasar kelapa. Kegiatan ini dilaksanakan 
INTEGRITAS : Jurnal Pengabdian

Vol 3, No 1, Juli 2019

ISSN 2580-7978 (Cetak) ISSN 2615-0794 (Online)

selama dua hari yaitu hari Sabtu-Minggu 11-12 Mei 2019 dari pukul 13.00 - 15.30 WIB. Pelaksanaan kegiatan dilaksanakan di rumah salah satu ketua RT yaitu Ibu Sulastri di lingkungan Desa Gelung, Kecamatan Panarukan.

Pelaksanaan kegiatan pelatihan pembuatan VCO (Virgin Coconut Oil) dengan bahan dasar kelapa ini diikuti oleh 12 ibu-ibu dan remaja putri dengan daftar nama sebagai berikut :

Tabel 3. Daftar Peserta Pelatihan

\begin{tabular}{|c|l|l|}
\hline No & \multicolumn{1}{|c|}{ Nama } & \multicolumn{1}{c|}{ Jabatan } \\
\hline 1 & Bu Sulastri & Ketua \\
\hline 2 & Bu Susmiati & Sekretaris \\
\hline 3 & Bu Satina & Bendahara \\
\hline 4 & Bu Nisa'iya & Anggota \\
\hline 5 & Sdir. Ratih & Anggota \\
\hline 6 & Sdri. Putri & Anggota \\
\hline 7 & Sdri. Nurfajriáh & Anggota \\
\hline 8 & Sdri. Prudence & Anggota \\
\hline 9 & Bu Rahmawati & Anggota \\
\hline 10 & Bu Hermin & Anggota \\
\hline 11 & Bu Noviyanti & Anggota \\
\hline 12 & Bu Yuni & Anggota \\
\hline
\end{tabular}

Adapun pokok bahasan kegiatan pelatihan PKM meliputi :

a. Pelatihan Pembuatan VCO (Virgin Coconut Oil)

b. Teori Pemasaran

c. Teori Manajemen keuangan UMKM

Dikarenakan keterbatasan waktu pertemuan mengakibatkan tidak semua materi dapat disampaikan secara terperinci.

Pelaksanaan kegiatan PKM diawali pada hari Sabtu tanggal 11 Mei 2019 dengan pemberian pelatihan kepada ibu-ibu dan remaja putri yaitu pelatihan pembuatan VCO (Virgin Coconut Oil), dimana proses awal pelatihan dimulai dengan pemberian dan pengenalan bahan dan alat yang digunakan, tercantum pada Tabel 4 berikut ini :

Tabel 4. Bahan dan Alat VCO (Virgin Coconut Oil) 
INTEGRITAS : Jurnal Pengabdian

Vol 3, No 1, Juli 2019

ISSN 2580-7978 (Cetak) ISSN 2615-0794 (Online)

\begin{tabular}{|l|l|l|}
\hline - Mesin parut kelapa & - Mixer & - Kelapa 12 buah \\
\hline- Baskom & - Toples transparan & - Air 3 liter \\
\hline - Saringan santan & - Penyaring minyak & - Botol Kemasan \\
\hline - Kain katun & - Sendok sayur pipih & - Label Kemasan \\
\hline $\begin{array}{l}\text { - Water dispenser } \\
\text { trnasparan }\end{array}$ & - Tissue non parfum & \\
\hline
\end{tabular}

Setelah bahan diberikan dan diperkenalkan, untuk tahap selanjutnya para peserta diberikan kesempatan untuk mempraktekkan pembuatan VCO (Virgin Coconut Oil). Tahapan pelaksanaan praktek pembuatan dari awal VCO (Virgin Coconut Oil) hingga selesai sebanyak 7 (tujuh) tahap, yaitu :

1. Kelapa dikupas bersih dan diparut halus,

2. Proses pembuatan santan kelapa,

3. Proses pengendapan santan kelapa,

4. Proses sentifugasi santan (mixer),

5. Proses santan didiamkan selama 12-36 jam,

6. Proses penyaringan VCO dari unsur air,

7. Produk VCO dipak dalam botol $100 \mathrm{ml}$.

Setelah praktek pembuatan $\mathrm{VCO}$ (Virgin Coconut Oil) selesai, tepatnya pada tanggal 12 Mei 2019 dilanjutkan dengan pelatihan manajemen diantaranya pemasaran dan keuangan UMKM serta evaluasi hasil kegiatan. Adapun rincian kegiatan tersebut adalah sebagai berikut :

\section{Pelatihan Teori Manajemen Produksi dan Keuangan}

Materi yang diberikan yaitu mengenai pengelolaan manajemen usaha mikro kecil menengah yaitu proses pemasaran dan keuangan. Beberapa permasalahan yang sering terjadi pada UMKM juga menjadi salah satu pembahasan dalam kegiatan pelatihan ini sebagai pedoman untuk meningkatkan jumlah wirausaha baru serta peningkatan pendapatan masyarakat khususnya ibu-ibu dan remaja putri di Desa Gelung Kecamatan Panarukan Kabupaten Situbondo. Masih minimnya pengetahuan peserta tentang proses pembuatan produk merupakan permasalahan yang paling utama, dan dengan dilaksanakannya praktek langsung pembuatan VCO (Virgin Coconut Oil) yang selanjutnya dibekali dengan bagaimana cara 
INTEGRITAS : Jurnal Pengabdian

Vol 3, No 1, Juli 2019

ISSN 2580-7978 (Cetak) ISSN 2615-0794 (Online)

mengelola bahan agar efektif dan efisien, hal tersebut nantinya akan semakin meningkatkan kesiapan para peserta untuk memulai usaha ini. Kegiatan ini diharapkan mampu untuk menciptakan dan meningkatkan nilai jual produk kelapa menjadi produk olahan yaitu VCO (Virgin Coconut Oil) di Kecamatan Panarukan, sehingga bisa meningkatkan pendapatan keluarga dan dapat menjadi industri rumah tangga yang handal yang dapat terus dikembangkan. Materi keuangan diarahkan dalam rangka untuk mengetahui tentang sumber permodalan usaha serta seberapa besar permodalan yang dibutuhkan untuk usaha tersebut. Dengan mengetahui prosesnya maka para ibu-ibu dan remaja putri akan bisa memulai manajemen usaha yang mandiri dan baik serta mampu mencatat keuangannya yaitu berupa besarnya biaya dan pendapatan yang diperoleh sehingga akan diketahui apakah usaha yang sedang mereka jalankan mengalami untung / rugi.

\section{Pelatihan Pemasaran}

Pelatihan tahap kedua diisi dengan pemberian materi yang membahas tentang pemasaran usaha dan bentuk badan usaha serta persyaratan-persyaratan untuk pendiriannya. Manfaat yang dapat diambil oleh para peserta dalam segi pemasaran diantaranya adalah sebagai berikut :

1. Model Label produk, merupakan bagaimana model label produk yang dibuat menarik perhatian konsumen untuk kemudian membelinya, hal yang terkandung dalam label ini didalamnya termasuk warna, bentuk, ukuran, kandungan, aturan pakai, kode produksi, kadaluarsa, nomer izin Depkes RI, produsen dan pemasaran produk yang akan dipasarkan.

2. Harga jual produk, merupakan penyesuaian antara total biaya produksi dan laba yang direncanakan, sehingga nantinya para peserta akan mengetahui harga jual produk yang sesungguhnya dimana akan menjadi bahan pertimbangan apakah harga yang ditawarkan mampu bersaing di pasaran atau tidak.

3. Promosi, merupakan langkah awal untuk memperkenalkan produk kepada masyarakat. Keputusan dengan pemanfaatan tekhnologi adalah yang paling 
INTEGRITAS : Jurnal Pengabdian

Vol 3, No 1, Juli 2019

ISSN 2580-7978 (Cetak) ISSN 2615-0794 (Online)

tepat. Media pemasaran online sangat membantu dalam rangka mempercepat proses pemasaran produk baik melalui media sosial Facebook, Instagram, WhatsApp dan lain-lain.

4. Distribusi, merupakan bagaimana membuat produk bisa sampai pada konsumen, penjualan bisa dengan cara direct selling atau penjualan langsung maupun secara online. Selain itu juga biasa dititipkan pada tempattempat wisata yang sedang digalakkan oleh BUMDes setempat seperti Rumah Apung, Grand Pathek dan lain-lain. Langkah-langkah pengenalan produk dengan cara langsung tersebut merupakan hal yang paling mudah untuk dilaksanakan bagi UMKM di masyarakat yang kemudian akan semakin dikenal dan diminati oleh masyarakat.

Setelah semua pelatihan selesai dilakukan, ibu-ibu dan remaja putri Desa Gelung Kecamatan Panarukan dapat mencoba mempraktekkan usaha tersebut dirumah masing-masing, yang nantinya diharapkan berawal dari penggunaan produk VCO tersebut untuk kesehatan sendiri dengan bahan herbal kemudian bisa membuka lapangan pekerjaan baru di masyarakat.

\section{Luaran yang Dicapai}

Berikut luaran yang telah dicapai atas pelaksanaan Program Kemitraan Masyarakat (PKM) adalah sebagai berikut :

1. Ibu-ibu dan remaja putri di Desa Gelung sudah mulai menyadari dan mengerti pentingnya peranan pengembangan agroindustri khususnya minyak VCO sebagai sarana penunjang kesehatan dan menambah pendapatan keluarga.

2. Peserta mengetahui peluang dan tantangan agroindustri VCO dengan benar dalam upaya meningkatkan ketrampilan dan pendapatan dari bidang pertanian.

3. Peserta bertambah pengetahuannya tentang teknologi pembuatan VCO pada skala rumah tangga secara optimal.

\section{KESIMPULAN DAN SARAN}


INTEGRITAS : Jurnal Pengabdian

Vol 3, No 1, Juli 2019

ISSN 2580-7978 (Cetak) ISSN 2615-0794 (Online)

\section{Kesimpulan}

Kondisi alam yang berubah-rubah tentunya sangat membantu perekonomian masyarakat dengan mengganti sumber pendapatan ekonomi utama dengan sumber pendapatan ekonomi lain, seperti pembuatan VCO. Selain kandungan nilai gizi yang dimiliki sangat bagus, hal ini pun memiliki nilai jual yang sangat tinggi, dengan penggunaan alat produksi yang sangat sederhana dan tidak mahal. Industri rumah tangga melalui pengolahan VCO tentunya akan menjadi sarana penunjang kesehatan dan menambah pendapatan keluarga bagi kelompok masyarakat pengolah serta ikut memberdayakan potensi hasil perkebunan yang dimiliki oleh desa itu sendiri.

\section{Saran}

Adapun saran yang dapat diberikan pada kegiatan PKM ini adalah upaya pengembangan agroindustri kelapa khususnya VCO pada skala rumah tangga dapat berlangsung secara intensif dan berkelanjutan di kalangan generasi muda, sehingga perlu diadakan sosialisasi secara intensif mengenai usaha pembuatan minyak VCO disertai dengan peningkatan peran instruktur yang tetap dibutuhkan untuk mendampingi para peserta dalam melakukan kegiatan ini.

\section{DAFTAR PUSTAKA}

Abdullah, Maskur. 2005. Lilitan Masalah Usaha Mikro kecil, Menengah (UMKM) dan Kontroversi Kebijakan. Medan: Bitra Indonesia.

Anoraga, Panji. 2002. Koperasi, Kewirausahaan, dan Usaha Kecil. Jakarta: Rineka Cipta.

Kotler, Philip, 2002, Manajemen Pemasaran, Jilid 2, Alih Bahasa oleh Hendra Teguh dkk, Edisi Milenium, Jakarta : PT Prenhallindo

Sutarmi dan Hartin Rozaline, 2005. Taklukkan Penyakit dengan VCO (Virgin Coconut Oil). Ed Cet 3.Penebar Swadaya. Jakarta. 
INTEGRITAS : Jurnal Pengabdian

Vol 3, No 1, Juli 2019

ISSN 2580-7978 (Cetak) ISSN 2615-0794 (Online)

Trubus, 2005. Pakar Bicara Minyak Perawan. Ed 427. Juni 2005. hal. 18-19. 